\title{
Underwater observations on the life cycle of Corymorpha nutans (Hydrozoa)
}

\author{
A. Svoboda \\ 1. Zoologisches Institut der Universität Wien, Lehrkanzel für Meeresbiologie; \\ Wien, Austria
}

\begin{abstract}
KURZFASSUNG: Unterwasserbeobachtungen über den Lebenszyklus von Corymorpba nutans (Hydrozoa). Corymorpba nutans $\mathrm{S}_{\mathrm{ARS}}$ ist ein athecater, solitärer mariner Hydroidpolyp, der in der Nordsee, dem Mittelmeer und im Schwarzen Meer verbreitet ist. Aus dem Mittelmeer ist bisher nur ein Fund des Polypen bekannt geworden. Seit 1969 wurden in Rovinj (Nordadria), stets zwischen Januar und Mai, eine größere Zahl von Polypen gefunden. Da zahlreiche große Polypen ohne Hydranthen angetroffen wurden, die wie Regenerate aus einem Ruhestadium aussahen, wurden einige Experimente zur Klärung des Lebenszyklus des Polypen im Freiland und im Labor ausgeführt. Hierzu wurden 15 Polypen im Freiland markiert und regelmäßig kontrolliert und parallel dazu ebensoviele im Labor gehalten. Die Resultate aus den Freiland- und Laboruntersuchungen waren identisch. Nach wenigen Wochen schrumptten die Polypen und verschwanden vom Substrat. Im Boden konnte kein Reservekörper nachgewiesen werden. Zwei Exemplare regenerierten nach dem Einschmelzen den Hydranthen. Daraus muß geschlossen werden, daß die Lebensdauer des Polypen nur eine Saison beträgt. Die im Freiland gefundenen Regenerationsstadien sind daher keine Aufwuchsstadien aus einem Reservekörper, sondern stammen von verletzten Polypen.
\end{abstract}

\section{INTRODUCTION}

Corymorpha nutans is an athecate solitary marine hydroid polyp found in the North Sea, the Mediterranean Sea and the Black Sea. Though the medusa (Steenstrupia rubra Forbes) is often found in the Adriatic Sea also (Hadzr 1911, Neppr 1912, Nepri \& STIASNY 1913, BabNik 1948), only a single specimen of the polyp has been found in Naples (LoBianco 1909). The main area of distribution of this species is the North Sea. Most of the findings have been made on the English and Norwegian shores (SARS 1860, Allman 1872, Rees 1937). But it seems, according to recent observations, that the polyp is also common in the Black Sea (STECHOw 1934, BÂCEscu 1952).

While the Californian species Corymorpha palma (Agassiz) is among the best studied species of the family, little is known about the biology of the polyp of Corymorpha nutans. The only observations on reproduction of this species have been made by Allman (1863), Rees (1937) and Werner (1959). According to Rees, the juvenile polyps hatch within one week after the egg has been expelled from the 
medusa. At this stage the polyp has already a perisarc tube and six oral and eight aboral tentacles. After one week the polyps attach themselves to the substrate by their stolon-like frustles ("holdfast", Campbell 1968), and two weeks later the blastostyle buds develop. According to WERNER (1959), only a small number of the polyps hatch after a week. A high percentage of the eggs develops only to the gastrula stage after becoming attached to the substrate. Further development occurs after a resting period of 9 to 21 months.

Nothing is known so far about the duration of the development from the newly hatched polyp to the production of medusae and about its life span. While collecting hydrozoans in Rovinj (Istria, Northern Adriatic Sea), polyps of Corymorpha nutans have been found regularly between January and May since the spring of 1969. Because the polyps showed great differences in size and because many stages of regeneration in different size could be distinguished, two modes of development seemed possible.

The first would be a development cycle lasting one season with the big polyps beginning their development soon after egg deposition, and the small polyps hatching later. The polyps would then disintegrate at the beginning of the summer. The next generation of polyps would develop from the eggs of the ripe medusae around autumn. The different stages of regeneration would be due in this case to injuries to the hydranth.

The second possibility would be a life span lasting several years. An individual of cold northern waters might survive comparatively high summer temperatures in a resting stage, analogous to the resting stage of many other Hydrozoa which can survive many months in form of stolons. A regeneration of the polyp from this resting stage would only start with the occurrence of lower water temperatures, and the many different stages of regeneration of big polyps could be explained. The feature of a long time of rest in the egg and the improbability of the big polyps having a life expectancy of only one season, suggest a life span of several years with intermediate resting stages.

To solve these questions experiments were carried out in the freld and in the laboratory.

\section{MATERIAL AND METHODS}

All polyps of Corymorpha nutans found so far in the Adriatic Sea have been recorded at Rovinj. They occur in low numbers on the shelf bottoms in depths between 15 and 38 meters. A higher density is observed on the shelf slopes of the islands where they reach a density of 1 to 10 specimen per $100 \mathrm{~m}^{2}$ in areas of flow velocities up to $10 \mathrm{~cm} / \mathrm{sec}$.

The stem of the smallest specimen found until now was $2.5 \mathrm{~cm}$ in height, and $3 \mathrm{~mm}$ in diameter; the diameter of the hydranth was $2 \mathrm{~cm}$. The hydranth carried 30 aboral and about 50 oral tentacles as well as 12 simple styloblasts with one complete medusa and some 12 medusa buds each, the buds showing different stages of development. The largest individuals were $20 \mathrm{~cm}$ high. The hydranth measured $8 \mathrm{~cm}$ in diameter. Nearly 100 aboral and 200 oral tentacles as well as 50 styloblasts were devel- 
oped. The styloblasts branched several times and each carried 3 to 5 complete medusae and up to 100 buds.

The average height of the polyps was 10 to $12 \mathrm{~cm}$, and the hydranth measured 5 to $6 \mathrm{~cm}$ in diameter. In addition to approximately 25 fully developed polyps, about 15 different stages of regeneration were found together with a few disintegrating polyps.

The author carried out all investigations, experiments, and collecting with SCUBA equipment. In January 1970, a strip for fieldwork, $2 \mathrm{~m}$ wide, $50 \mathrm{~m}$ long, and ranging between 30 and $38 \mathrm{~m}$ depth, off the island of Banjole was marked by wooden pegs.
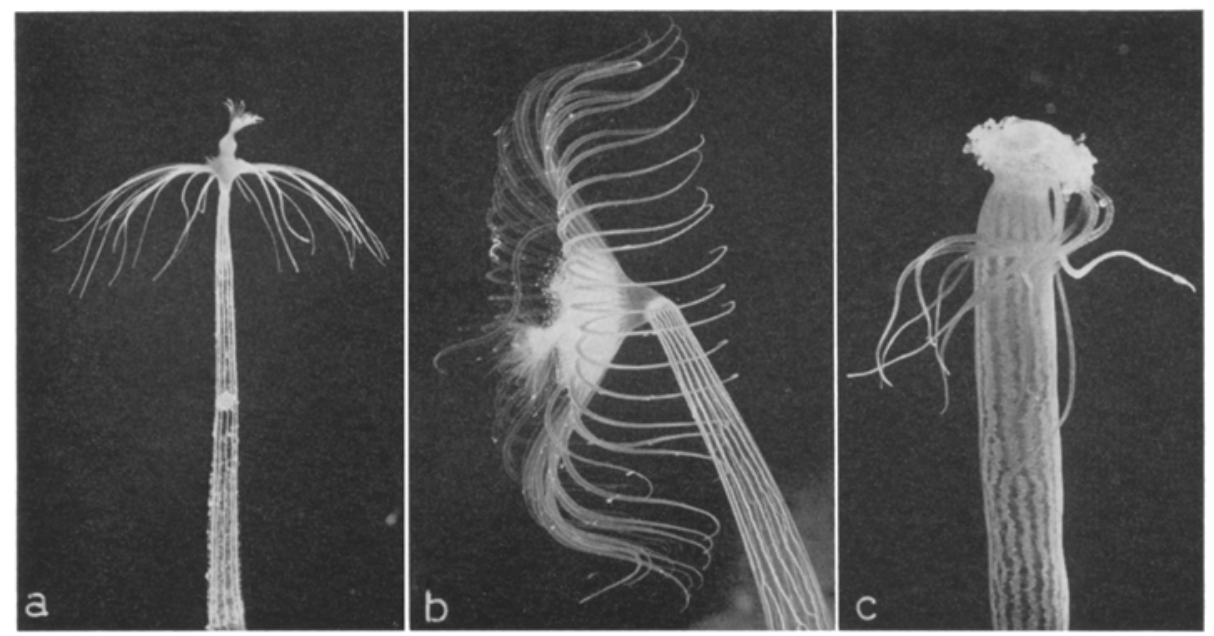

Fig. 1: Corymorpba nutans. Life stages of the polyp. $a$ young polyp; $b$ adult polyp; $c$ disintegrating polyp

The polyps which occurred in this area were marked in three different ways so as to facilitate recovery. Five polyps were identified by applying rings of stainless steel wire; such marking could be done without disturbance. Five others were dug up and put into stainless steel wire baskets which were immediately re-inserted into the substrate. Another 5 polyps were implanted in glass dishes in the same way. The experiments were checked daily during the first week after the marking, later monthly or bi-monthly. When the polyps had disappeared from the surface of the substrate at the end of May, two samples were taken from each type of marking and examined in the laboratory. The marked pieces of substrate which remained in the field were checked again in spring, 1971, and examined in the laboratory at the end of May.

For all histological examinations the hydrozoans were fixed with Bouin's fluid or sublimate solution, and the sections were stained in haematoxyline-eosin.

For laboratory experiments, the polyps were implanted in glass dishes and kept in aerated and filtered aquaria at $10^{\circ} \mathrm{C}$. Food consisted of brine shrimp larvae. Two weeks later, after the disappearance of the polyps, the parts remaining in the substrate were examined histologically. 


\section{RESULTS}

The experiments conducted in the field and in the laboratory yielded the same results. At first the polyps grew a little in size while continuously producing medusae, When nearly all medusae had been set free, most of the aboral tentacles were cast off at their base. After reduction of the oral tentacles, the proboscis began to shrink. At this stage the remaining aboral tentacles were cast off, whereupon the hydranth disintegrated. As soon as this process reached the stem, its distal end was closed by the stem ectoderm. In the course of a week, the stem, beginning with the distal end, shrank until it disappeared in the substrate.

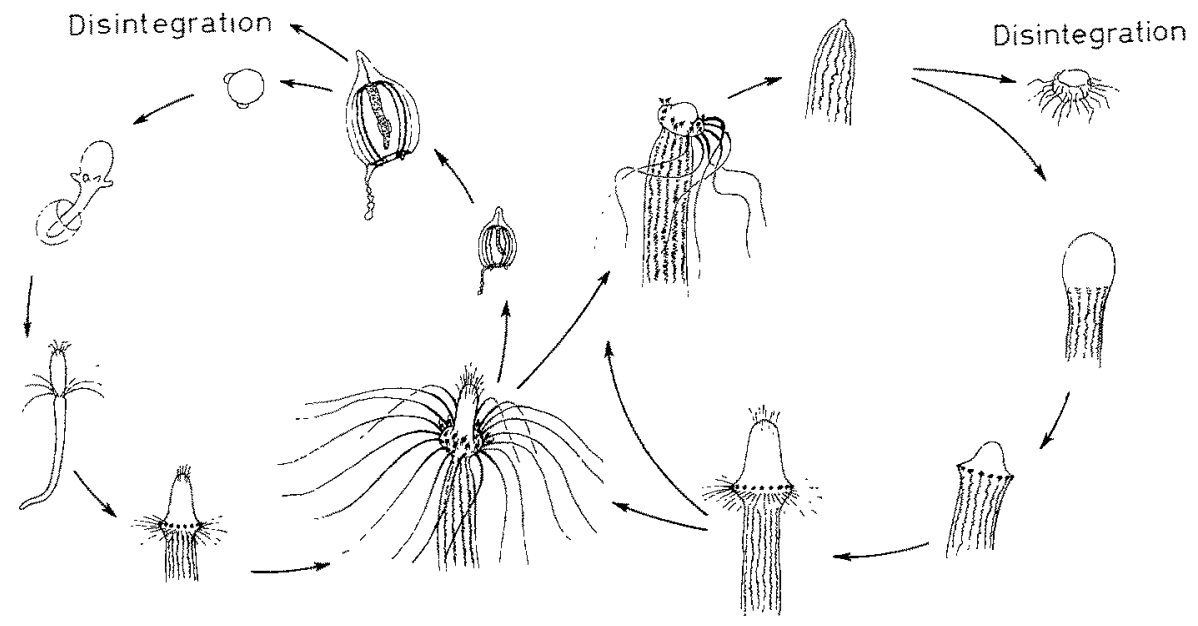

Fig. 2: Corymorpha nutans. Development, regeneration and senescence

The rest remaining in the substrate consisted only of a bird-nest-like bull of periderm which a histological examination showed to be free of cells. Therefore, no polyps developed in the following spring from the marked specimen that remained in the field. After a year the remaining parts of periderm could not be detected any more in the substrate. In two cases, hydranths regenerated from the stem after their disintegration in the laboratory, and on several occasions the regeneration took place in specimens found in the field without hydranth. Regeneration proceeded the same way as in Corymorpha palma (TorRex 1910) and in decapitated polyps of Corymorpha nutans. At $10^{\circ} \mathrm{C}$, regeneration took 3 to 4 days (development of styloblast buds). The regeneration begins with a ball-like swelling of the distal stem portion. At the base of this swelling, buds of the aboral tentacles can be distinguished near the longitudinal channels after one day. The swelling then usually becomes cone shaped at the distal end and reveals the first oral tentacle buds after a further day. When the aboral tentacles reach 5 to $10 \mathrm{~mm}$ in length, a row of styloblasts develops between them and the oral tentacles. The styloblasts begin branching in the course of a further week, but do not develop medusae in the laboratory. The hydranth stops growing after having 
reached half of its former diameter and disintegrates after a few weeks in the same way as fully developed polyps.

\section{DISCUSSION}

The results of this investigation show clearly that the polyp of Corymorpha nutans has a maximal life span of one season, not considering the period of rest in the gastrula stage. The stages of regeneration found in the field, therefore, are not stages of upgrowth from a storage bud, but originate from injured polyps or from senile, disintegrating hydranths. The cause of the mechanical injuries remains unknown, but feeding of fishes or crustaceans (e.g. Maia squinado) on hydranths cannot be excluded. Senescence is known from stolonial hydroids (ToTH 1969) but has not been described for Corymorpha nutans. Furthermore, it is not yet known whether Corymorpha nutans appears periodically in the Adriatic Sea only. According to literature reports, the medusa Steenstrupia rubra should occur also periodically in the North Sea, but further into the summer because of low water temperatures. One other explanation would be that the high water temperatures in the Mediterranean Sea are the only reason for the disintegration of the polyps and that in colder seas the polyps are perennial. Indications supporting this view are lacking so far.

A more detailed study of the life cycle of Corymorpha nutans would necessitate culturing of the hydrozoans in the laboratory and taking time-lapse pictures in the field, in order to close the gaps in documentation. Further biological and histological examinations are under way.

\section{SUMMARY}

1. Only one specimen of Corymorpba nutans SARS has been found in the Mediterranean Sea near Naples until now.

2. A greater number of individuals of this species has been recorded from Rovinj, Northern Adriatic, since 1969 but only between January and May.

3. The individuals found measured between 2.5 and $20 \mathrm{~cm}$ in height. 'The hydranth's diameter reached a maximum of $20 \mathrm{~cm}$.

4. The occurrence of big regenerating specimen led to the conclusion that the polyps live for several years and grow up annually from a summer resting stage.

5. Experiments with marked polyps conducted in the field and in the laboratory proved that no storage body is formed at the end of the season and that the polyps, therefore, live for one season only.

6. Regeneration of polyps which disintegrate because of senescence takes place in the same way as in Corymorpha palma or decapitated polyps.

7. The reasons for the different stages of regeneration found in the field are discussed, and the life cycle of Corymorpba nutans in Northern seas considered.

Acknowledgements. The author wishes to express his thanks to Dr. B. WERNER, Biologische Anstalt Helgoland, for stimulating further observations, and to R. MACHAN for transm lation and criticism. The field work was supported by the Austrian "Fonds zur Förderung der wissenschaftlichen Forschung" (projects 798, 1305, and 1113). 


\section{LITERATURE CITED}

Altman, G. J., 1863. Notes on the Hydroidea. 1. On the structure of Corymorpha nutans. Ann. Mag. nat. Hist. 11, 1-8.

- 1872. A monograph of the gymnoblastic or tubularian hydroids. II. The genera and species of the Gymnoblastea. Ray Society, London.

Babnik, P., 1948. Hydromedusae from the middle and south Adriatic 1939 and 1940. Acta adriat. $3(9), 1-68$.

BÂCESCu, M., 1952. Hidropolip sau actinie - Corymorpha ori Cerianthus - este celenteratul caracteristic fundurilor cu Modiola din marea neagra? Comunle Acad. Rep. pop. rom. 2, 233-237.

CAMPBeLL, R. D., 1968. Holdfast movements in the hydroid Corymorpha palma: Mechanism of elongation. Biol. Bull. mar. biol. lab., Woods Hole 134, 26-34.

Hadzi, J., 1911. Uber die Dislokation und Migration der Knidozyten bei den Hydromedusen und bei den Hydroiden überhaupt. Rad. jugosl. Akad. Znan. Umjetn. 50, 141-247.

LoBianco, S., 1909. Notizie biologiche reguardanti specialmente il periodo di maturita sessuale degli animali del Golfo di Napoli. Mitt. zool. Stn Neapel 19, 513-761.

Neppr, V., 1912. Adriatische Hydromedusen. Sber. Akad. Wiss. Wien (Math. nat. Kl.) 121 (Abt. 1), 709-734.

- \& Strasny, G., 1913. Die Hydromedusen des Golfes von Triest. Arb. zool. Inst. Univ. Wien 20, 23-92.

REes, W. J., 1937. The development of the hydroid Corymorpha nutans M. SARs from the egg. J. mar. biol. Ass. U. K. 21, 743-746.

SARS, M., 1860. Uber das Ammengeschlecht Corymorpha und seine Arten, nebst den von diesen aufgeammten Medusen. Arch. Naturgesch. 26, 1, 341-351.

STECHOW, E., 1934. Vorkommen eines nordischen Hydroiden Corymorpha sarsi STEENSTRUP im Schwarzen Meer. Zool. Anz. 107, 197-198.

TorReY, H. B., 1910. Biological studies in Corymorpha. III. Regeneration of hydranth and holdfast. Univ. Calif. Publs Zool. 6, 205-221.

Tотн, S. E., 1969. Aging and regression in the colonial hydroid Campanularia flexuosa with special teference to senescence in hydroids. Int. Revue gen. exp. Zool. 4, 1-79.

WERNER, B., 1959. Dauerstadien bei marinen Hydrozoen. Naturwissenschaften 7, 1-3.

Author's address: A. SvoBoDA

I. Zoologisches Institut

Universität Wien

Lehrkanzel für Meeresbiologie

A-1090 Wien

Währingerstr. 17

Austria 